\title{
Vegetation succession and soil cover transformation after extreme flood: \\ A case study from the Sázava River floodplain
}

\author{
TOMÁŠ CHUMAN \\ Charles University in Prague, Faculty of Science, \\ Department of Physical Geography and Geoecology
}

\begin{abstract}
The goal of this study was to assess impact of flood on soil and vegetation cover in the Sázava river floodplain after an extreme spring flood in 2006. The impact on soil cover resulted mainly in vast erosion and sedimentation leading to differentiation of three fluvisol subtypes according to sediment coarseness. The impact on vegetation resulted in regeneration of herbaceous alluvial vegetation buried under a thin layer of sediments, succession of vegetation on eroded sites and succession of vegetation on new sediments. The regeneration of alluvial vegetation, expressed by vegetation cover, reached the same level as vegetation on undisturbed sites after 8 months. The succession of vegetation on new sites, studied within $25 \mathrm{~m}^{2}$ sampling plots and tested by using multivariate statistical methods, was primarily dependent on diaspores left on sites by the flood and on site type as well. The vegetation cover reached 100 percent at the end of the first vegetation season in both cases. There was a significant difference in species' composition between eroded sites and sites on thick layers of sediments each year as hypothesized. There was also significant difference in vegetation succession between site types.
\end{abstract}

Key words: floods, floodplain, succession of vegetation, soil cover, Sázava

\section{Introduction}

Floodplains belong to the youngest and most dynamics segments of the landscape. The dynamics is driven by natural as well as cultural processes. Regular floods represent natural disturbances of the floodplain that drive the pattern of vegetation and influence the pedogenesis (Geerling et al. 2006).

In alluvial plains along water courses, where periodical floods occur, the vegetation cover is composed of a mosaic of transient stages from more to less stable formations. The extent and proportion of areas with specific vegetation stages are a result of flood frequency and kinetic energy of every flood as well as site conditions e.g. sediment type, moisture regime etc. Floods eliminate species that are not adapted to flooding in terms of lack of oxygen and mechanical destruction by transported material. On the other hand floods support less competitive species and are essential for native floodplain vegetation. Duration and timing together with flood energy are crucial ecological factors influencing floodplain vegetation (Townsend 2001). Floods during non-growing season affect floodplain vegetation less severely than floods during growing season. Moreover floods during growing season bring a large amount of seeds 
and affect spread of species along the stream. They are especially favorable for spread of invasive species (Matějček 2007). However in the Czech Republic most floodplains have been modified to the extent that it is difficult to predict response of the ecosystem to floods. The modifications tended to prevent regular flooding and mostly lead to changes in land use and species composition. Such modifications however do not prevent extreme floods that have consequently more severe impact on the altered floodplain than on the floodplain in natural state.

The purpose of this paper is to describe impact of an extreme flood on soil cover and succession and/or regeneration of vegetation after such event in the Sázava river floodplain. Even though several researches with the same goal have been published for the Czech Republic (Kovář et al. 2002, Blažková 2003, Koutecký 2003), these studies focused either on succession of vegetation on new sediments or regeneration of alluvial vegetation. For example Kovár et al. (2002) studied succession of vegetation after floods in the Morava river floodplain in 1997. The agricultural land abandoned due to the floods was dominated by invasive plant species e.g. Solidago gigantea, Impatiens glandulifera and woody plant species e.g. Salix triandra, Salix purpurea, Salix caprea, Alnus glutinosa. Five years after the floods the mosaic of herbal, shrub and potentially forest stages of succession was present. A research in the Bečva river floodplain after the floods in 1997 (Lacina et al. 1998) brought the same conclusions.

Vast erosion and following succession of vegetation as documented in the Sázava river floodplain has not been studied so far. The extreme spring flood resulted in regeneration of herbaceous alluvial vegetation buried under a thin layer of sediments, succession of vegetation on eroded sites and succession of vegetation on new sediments deposited in the eroded part of the floodplain. I hypothesized that the rate of revegetation depended on the site type (buried vegetation / erosion site / sedimentation site). I also hypothesized that the vegetation of erosion sites and sedimentation sites differed in species composition as different diaspores are more likely to spread with water unlike with sediment.

\section{Material and methods}

The study area of $65000 \mathrm{~m}^{2}$ is located in the Sázava River floodplain near the town Čerčany (Fig. 1). The extent and impact of the flood on soil and vegetation cover was documented here by using soil cover mapping and $5 \times 5 \mathrm{~m}$ vegetation permanent plots using Braun-Blanquet approach. The vegetation cover was estimated every two month during the first year after the flood. Vegetation relevés were conducted during the period of maximum vegetation development in June each year. 3 permanent study plots were situated in the part of the floodplain where meadow herbaceous vegetation was buried under loamy to sandy sediments up to $10 \mathrm{~cm}$ thick, 5 plots were situated in the eroded part of the floodplain and 5 plots in the eroded part with more than $30 \mathrm{~cm}$ thick layer of loamy to sandy sediments deposited with flood retreat. Univariate analysis of obtained data was carried out by means of Statistica and multivariate analysis of vegetation data were carried out by means of CANOCO. Map of the study area was produced by means of ArcGIS 9.2. 


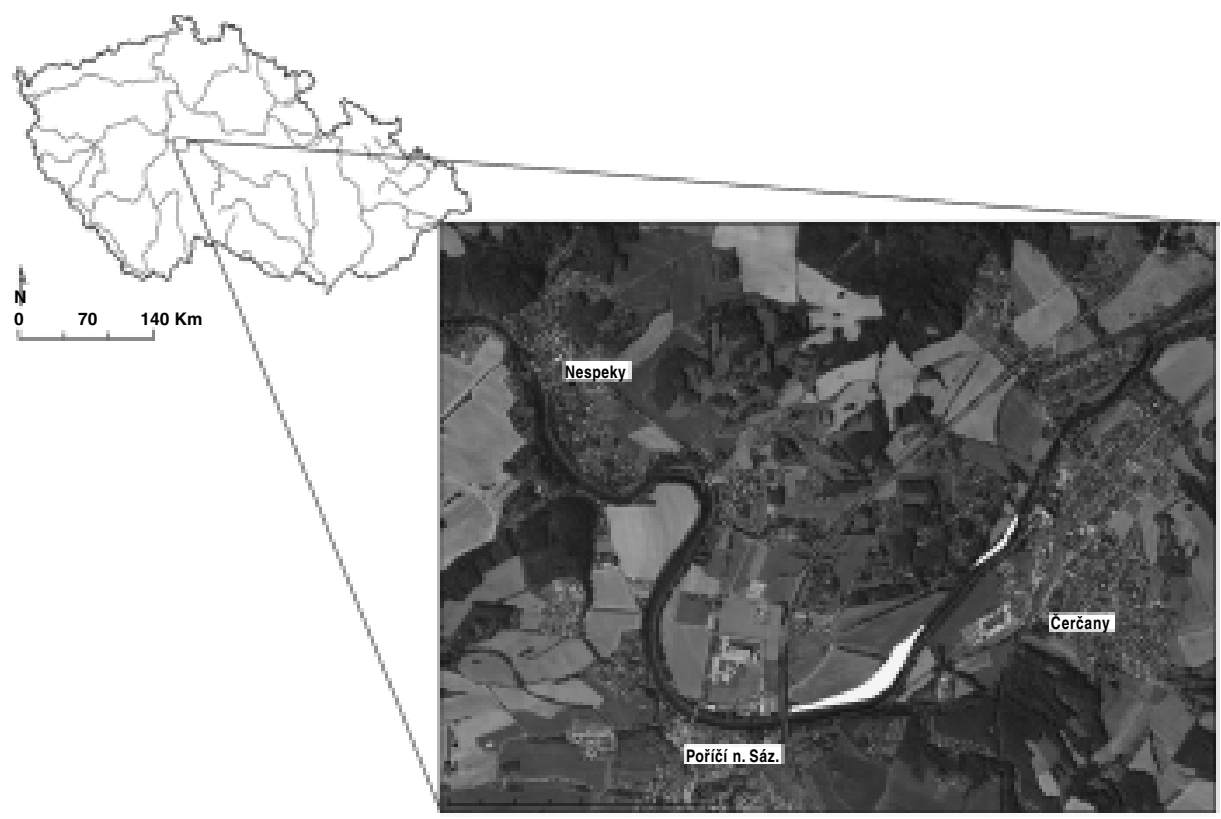

Fig. 1: Study area with highlighted parts of the Sázava River floodplain containing study plots. (Source: www.cenia.cz)

\section{Results}

In the study part of the Sázava River floodplain vast erosion and sedimentation were documented. The area of $49000 \mathrm{~m}^{2}$, previously converted into arable land, was severely affected. Complete Ap soil horizon was eroded disclosing compacted subsoil. The compacted subsoil was eroded as well into a depth of 5 to $10 \mathrm{~cm}$ in form of rill erosion or small evorsion hollows (Fig. 2). Furthermore two large lagoons $540 \mathrm{~m}^{2} \times 1.5 \mathrm{~m}$ deep and $930 \mathrm{~m}^{2} \times 2 \mathrm{~m}$ deep were created in the floodplain. The estimated volume of the eroded material was $17000 \mathrm{~m}^{3}$ from the area of $49000 \mathrm{~m}^{2}$.

The subsiding flood left substantial volume of loamy to sandy or locally gravel sediments, causing diversification of previous modal fluvisol into 3 subtypes: arenic, siltic to cleyic and skeletic fluvisol. The sedimentation occurred in the previously eroded part of the floodplain as well.

The impact of the flood on vegetation cover was as follows:

- Regeneration of herbaceous alluvial vegetation buried under thin layer (up to $10 \mathrm{~cm}$ thick) of loamy to sandy sediments.

- Succession of vegetation on two types of sites: eroded sites and loamy to sandy sediments. There was also gravel sediment but due to the small extent this type of site was not included in the study. Sampling and analysis were carried out only on two types of sites: eroded and sedimented.

The regeneration of herbaceous alluvial vegetation buried under sediments was initiated in parts of floodplain with alluvial meadow vegetation. The regeneration 


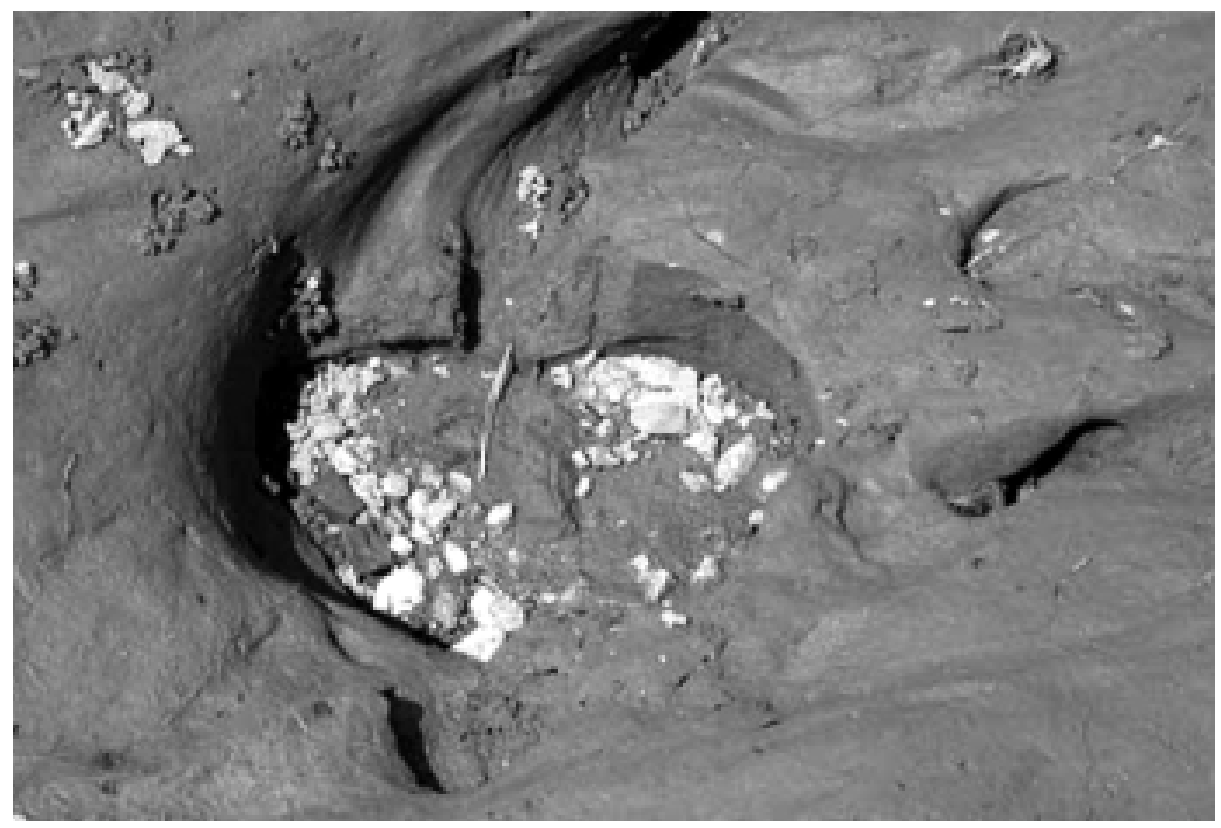

Fig. 2: Evorsion hollows formed in the compacted subsoil. The shape and origin resemble potholes

appeared to be relatively fast as 2 month after the flood the vegetation cover was $20 \%$ compared to $100 \%$ cover of undisturbed sites of the floodplain. After next 2 months vegetation cover reached $70-100 \%$ and 8 months after the flood the vegetation cover reached the same extent as undisturbed parts of the alluvial meadow. Besides regeneration of autochtonous plant species intergrowing the sediments, e.g. (Aegopodium podagraria, Alopecurus pratensis, Geranium pratense, Phleum pratense, Sanguisorba officinalis) alochtonous plant species occured as well (Artemisia vulgaris, Bidens tripartita, Calystegia sepium, Chenopodium sp., Galinsoga parviflora, Impatiens glandulifera, Melilotus officinalis, Ranunculus repens, $R$. pratensis, Sisymbrium officinale, Stellaria media, Urtica dioica). Disapores of those species were deposited by the flood on sites.

The revegetation of eroded and sedimented sites was also unexpectedly fast. The vegetation cover was less than $5 \%$ two months after the flood but reaching $75-100 \%$ 2 months later on both types of sites. This rapid revegetation was due to germination of annual species whose seeds were deposited by the flood. Impatiens glandulifera was the dominant species of the sediments. Annual species belonging to the class Chenopodietea and Bidentetea were the dominants of the erosion plots.

There was no significant difference in the revegetation speed among sites (meadow, eroded and sedimented sites). There was nonetheless significant difference in species composition between eroded sites and sites on thick layers of sediments each year $(\mathrm{P}<0.05)$ as hypothesized. There was also significant difference in the temporal trend between site types $(\mathrm{P}<0.05)$. 


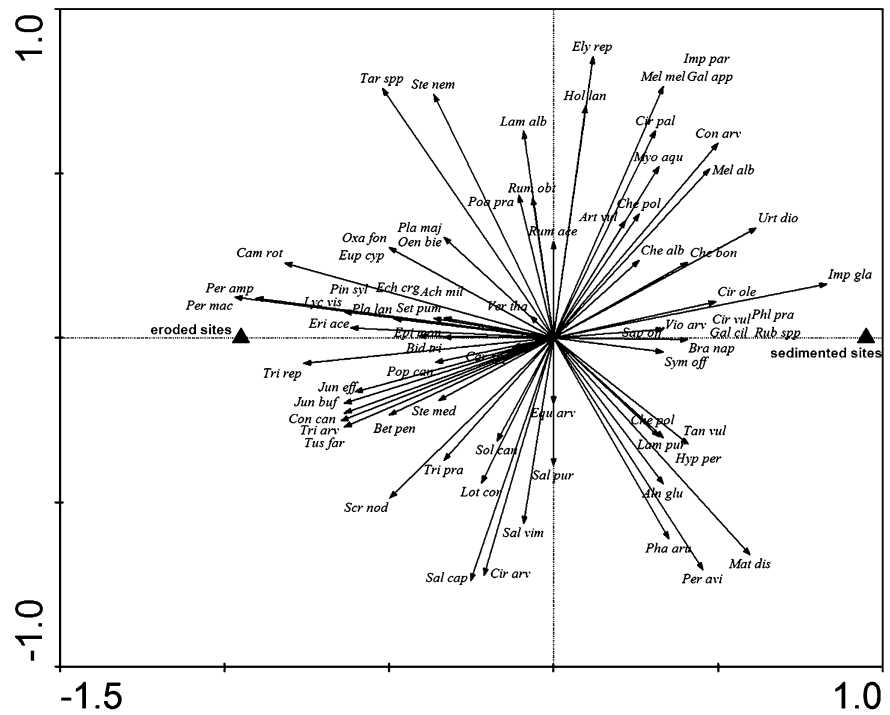

Fig. 3: RDA analysis of species composition and site type in the year 2006. The ordination biplot shows species more likely associated with eroded sites on the left side of the diagram and species more likely associated with sedimented sites on the right side of the diagram

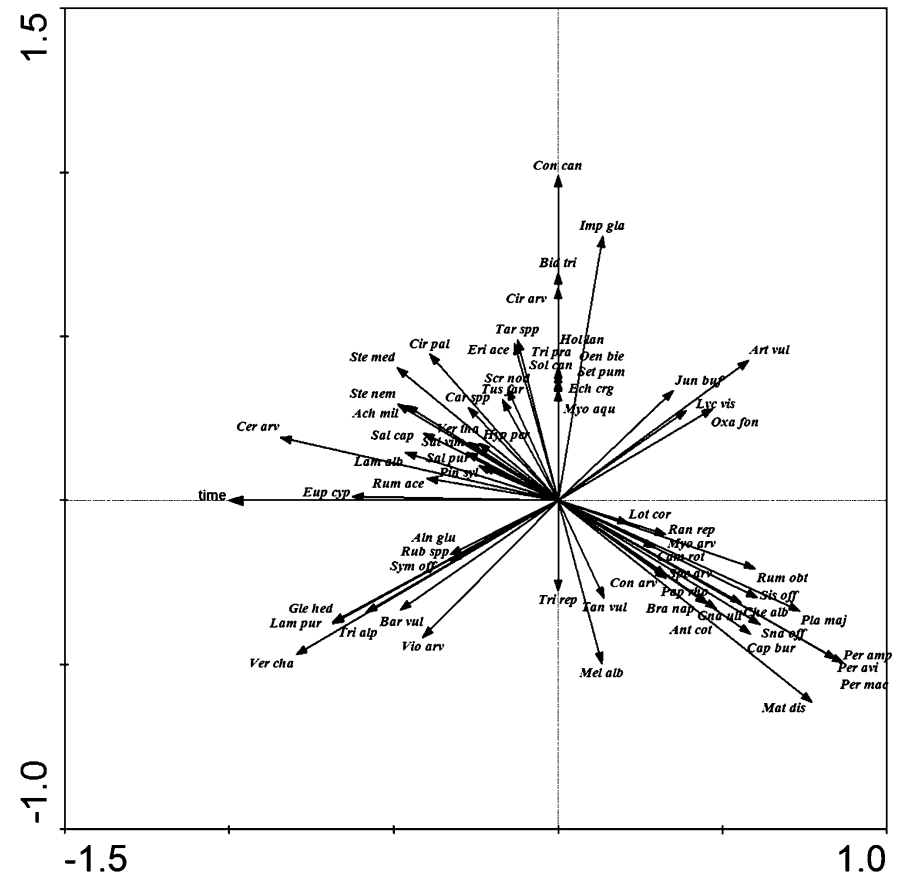

Fig. 4: RDA analysis of temporal trend of species composition on eroded sites. Species ordination biplot indicates which species are more likely to increase or decrease cover during the succession. (Species with more than $5 \%$ fit are displayed.) 


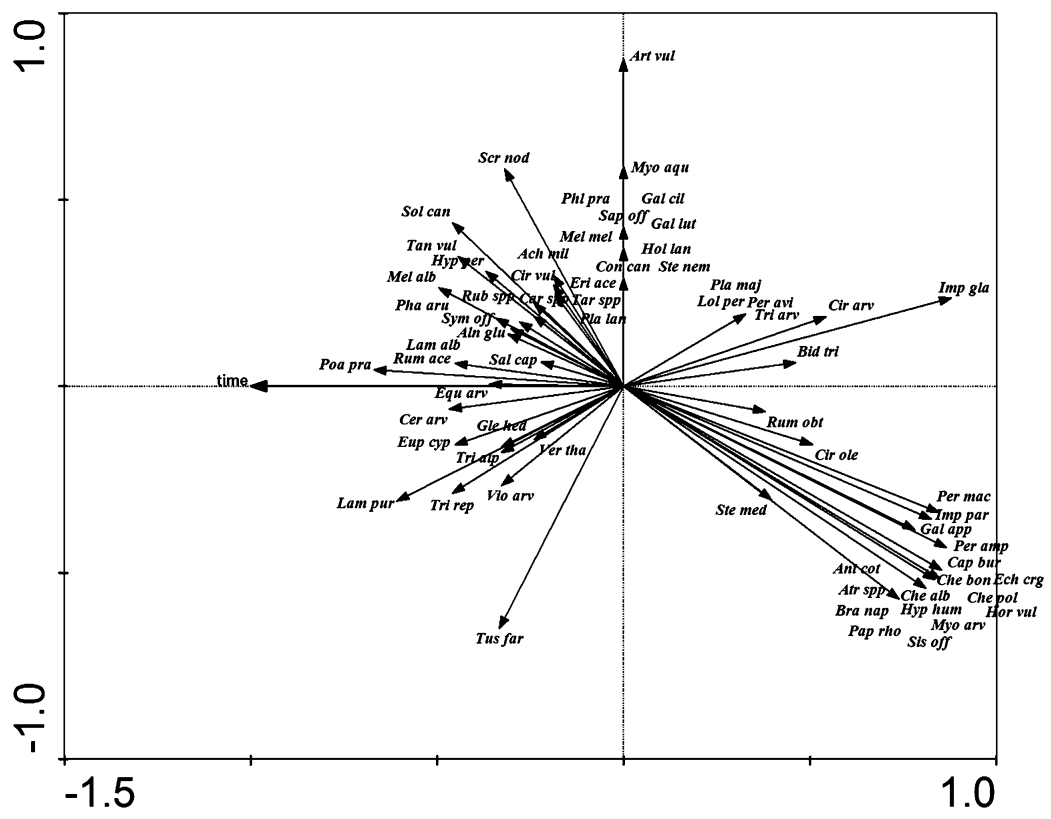

Fig. 5: RDA analysis of temporal trend of species composition on sedimented sites. Species ordination biplot indicate which species are more likely to increase or decrease cover during the succession. (Species with more than $5 \%$ fit are displayed.)

(Ach mil - Achillea millefolium, Aln glu - Alnus glutinosa, Ant cot - Anthemis cotula, Atr spp - Atriplex sp., Art vul - Artemisia vulgaris, Bar vul-Barbarea vulgaris, Bet pen - Betula pendula, Bid tri - Bidens tripartitus, Bra nap - Brasica napus napus, Cam rot - Campanula rotundifolia, Cap bur - Capsella bursa-pastoris, Car spp - Carex sp., Cer arv-Cerastium arvense, Cir arv - Cirsium arvense, Cir ole - Cirsium oleraceum, Cir pal - Cirsium palustre, Cir vul - Cirsium vulgare, Con arv - Convolvulus arvensis, Con can - Conyza canadensis, Ech crg - Echinochloa crus-galli, Ely rep - Elytrigia repens, Epi mon - Epilobium montanum, Equ arv - Equisetum arvense, Eri ace - Erigeron acer, Eup cyp - Euphorbia cyparissias, Gal app Galium apparine, Gal cil - Galinsoga parviflora, Gal lut - Galeobdolon luteum, Gle hed Glechoma hederacea, Gna uli - Gnaphalium uliginosum, Hol lan - Holcus lanatus, Hor vulHordeum vulgare, Hyp hum - Hypericum humifusum, Hyp per - Hypericum perforatum, Che alb - Chenopodium album, Che bon - Chenopodium bonus-henricus, Che pol-Chenopodium polyspermum, Imp gla - Impatiens glandulifera, Imp par - Impatiens parviflora, Jun buf Juncus bufonius, Jun eff - Juncus effusus, Lam alb - Lamium album, Lam pur - Lamium purpureum, Lot cor - Lotus corniculatus, Lol per - Lolium perenne, Lyc vis - Lychnis viscaria, Mat dis - Matricaria discoidea, Mel alb - Melandrium album, Mel mel - Melittis melissophyllum, Myo aqu - Myosoton aquaticum, Myo arv - Myosotis arvensis, Oen bie Oenothera biennis, Oxa fon - Oxalis fontana, Pap rhoe - Papaver rhoeas, Per amp - Persicaria amphibia, Per avi - Persicaria aviculare, Per mac - Persicaria maculosa, Pha aru - Phalaris arundinacea, Phl pra - Phleum pratense, Pin syl - Pinus sylvestris, Pla lan - Plantago lanceolata, Pla maj - Plantago major, Poa pra - Poa pratensis, Pop can - Populusxcanadensis, Ran rep - Ranunculus repens, Rub spp - Rubus sp., Rum ace - Rumex acetosa, Rum obt-Rumex obtusifolia, Sal cap - Salix caprea, Sal pur - Salix purpurea, Sal vim - Salix viminalis, Sap off - 
Saponaria officinalis, San off - Sanguisorba officinalis, Scr nod - Scrophularia nodosa, Set pum - Setaria pumila, Sis off-Sisymbrium officinale, Sol can - Solidago canadensis, Spe arvSpergula arvensis, Ste med - Stellaria media, Ste nem - Stellaria nemorum, Sym off-Symphytum officinale, Tan vul - Tanacetum vulgare, Tar spp - Taraxacum sp. (officinale), Tri alp - Trifolium alpestre, Tri arv - Trifolium arvense, Tri pra - Trifolium pratense, Tri rep - Trifolium repens, Tus far - Tussilago farfara, Urt dio - Urtica dioica, Ver cha - Veronica chamaedrys, Ver tha Verbascum thapsus, Vio arv - Viola arvensis)

\section{Discussion}

Being aware that the final number of study plots is rather low, the dynamics, rate and direction of spontaneous vegetation regeneration as well as impact of extreme flood event on soil cover is presented in this article. Number of study plots is low because of no more study plots remained untouched for the study period. The presence of drying lagoons, accumulations and succession stages - generally the "disarrangement" induced people to fill lagoons with diverse waste and movement of vehicles unfortunately disturbed several study plots.

The described changes in soil cover represent natural disturbance of the floodplain. However such vast erosion has not been documented so far. It could be suggested that the Sázava River channel line was deflected causing vast erosion of the floodplain due to the force of tributary in flood called Benešovský brook.
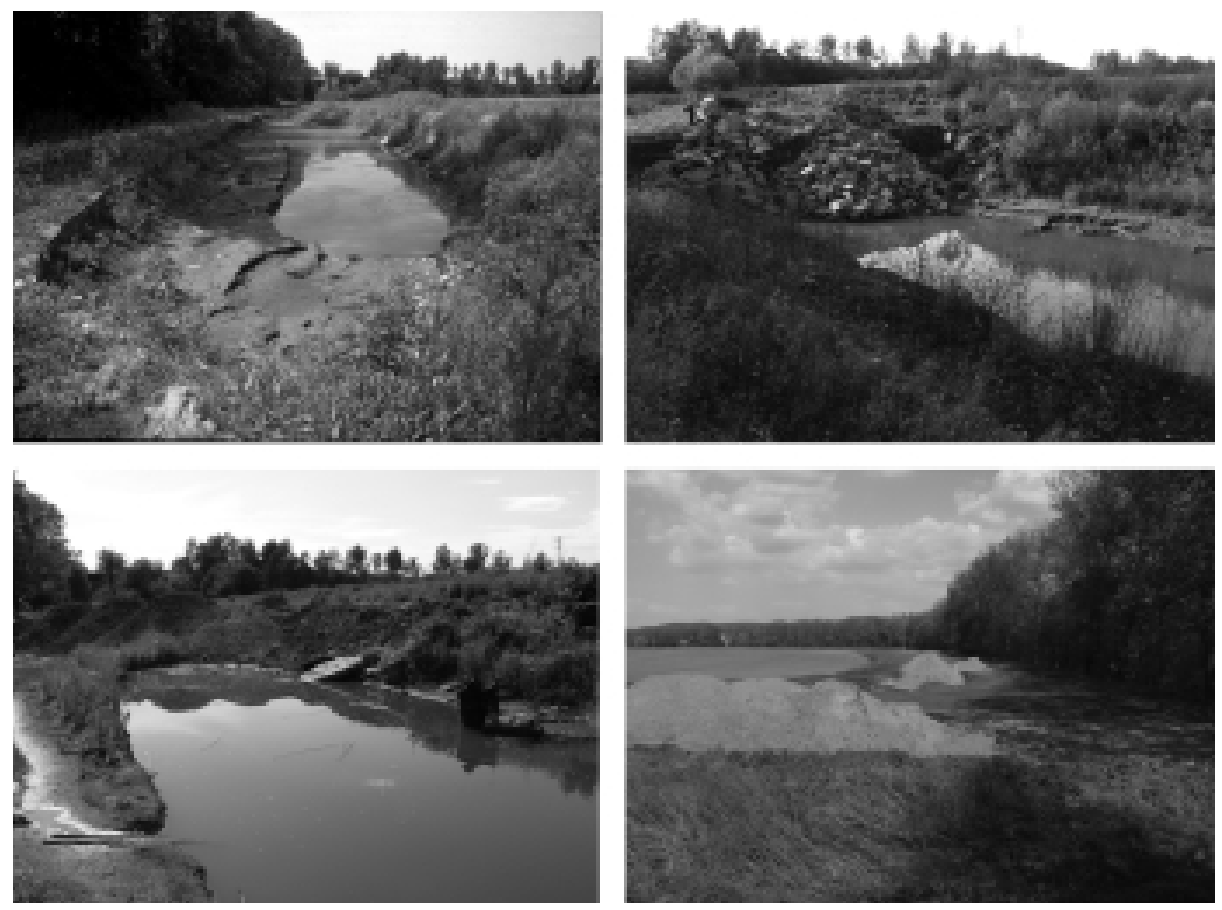

Fig. 6-9: Disappearance of eroded lagoon from June 2006 to May 2008 
The impact of flood was more severe in part of the floodplain converted into arable land. The compacted subsoil of different physical characteristics than eroded Ap horizon (Hamzaand \& Anderson 2005) probably worked as slip plane furthermore evorsion lead to formation of two large lagoons and numerous "potholes".

The rate of revegetation and/or regeneration was unexpectedly fast even on eroded sites where the complete removal of soil seed bank was expected. The reason could be seen in nutrient rich soils, favourable moisture regime and rich seed bank deposited by the floodwater and sediments. The vegetation cover of the meadow study plots reached the same cover faster in the Sázava river floodplain than presented by Koutecký (2003) from the Morava river floodplain. The reason could be ascribed to short term flooding that did not lead to death of vegetation due to lack of oxygen. The regeneration of vegetation was accelerated by restoring previous land-use - regular mowing in case of meadow vegetation. The movement of agricultural mechanization, when mowing, lead to sediment dispersion furthermore, mowing lead to elimination of alochtonous plant species mainly of Impatiens glandulifera. In the next vegetation season the vegetation cover and composition did not show any signs of flood disturbance. Generally the regeneration of native floodplain vegetation is fast since species have evolved life strategies that enable them to quickly colonize large areas. The ability of certain species to regenerate depends mainly on the depth of flood water, duration of flooding and thickness of sediment.

The species composition differed neither on eroded sites nor on sedimented sites from previously published research after extreme floods (Blažková 2003). The dominant plant species were Impatiens glandulifera on the sedimented sites and annual species belonging to the class Chenopodietea and Bidentetea on eroded sites in the first vegetation season. The mentioned species composition is a result of high seed production and way those species spreads. Seeds of Bidentetea or Chenopodietea spreading with water flow were captured in "pot holes" and rills; on the other hand bythisohydrochory is an important way of Impatiens glandulifera spreading (Slavík ed. 1997). The proximity of sites was also a great advantage, as the potential species pool was the same and also the sites did not differ in climate or precipitation. Therefore difference in vegetation development was most likely due to edaphic or hydric conditions, available species pool and "post flood" land-use.

The temporal trend of species composition shows transition towards more mesophilous species on both types of sites eg. Poa pratensis, Lamium album, Lamium purpureum, Melandrium album, Tanacetum vulgare, Phalaris arundinacea, Hypericum perforatum, Glechoma hederacea, Cerastium arvense, Barbarea vulgaris, Viola arvensis, Veronica chamaedris, Euphorbia cyparissias and also invasive plant species Solidago canadensis spreads. Species that dominated in the first vegetation season have been decreasing in cover e.g. Chenopodium album, Chenopodium polyspermum, Impatiens glandulifera, Impatiens parviflora, Persicaria amphibia, Persicaria aviculare, Persicaria maculosa, Artemisia vulgaris, Brasica napus napus, Matricaria discoidea.

Seedlings of trees appeared also in the first vegetation season after the flood. The Populus $x$ canadensis was the most common species in the first year on eroded plots. Erosion disclosed roots of adult trees of Populus $x$ canadensis, forming the riparian 
vegetation, enabling reproduction by root suckering (Naiman \& Décamps 1997). Number of individual tree saplings as well as number of tree species is increasing within whole floodplain e.g. Alnus glutinosa, Betula pendula, Populus x canadensis, Salix caprea, $S$. purpurea, S. viminalis.

In the Morava river floodplain (Kovář et al. 2002) and the Bečva river floodplain (Lacina et al. 1998) the research documented that five years after floods the mosaic of herbal, shrub and potentially forest stages of succession was present, dominated by invasive plant species e.g. Solidago gigantea, Impatiens glandulifera and woody plant species e.g. Salix triandra, Salix purpurea, Salix caprea, Alnus glutinosa. The formation of transient stage of shrubs and herbs could be expected in the Sázava river floodplain as well.

\section{Conclusion}

The three year monitoring after the extreme flood enabled to asses the impact of the flooding on altered floodplain. The impact on soil cover was severe due to unsuitable land-use. The response of semi-natural vegetation to flooding was positive. The presence of eroded sites and sedimented sites enabled the comparison of seed bank differences deposited on sites. The research confirmed that floods are a natural part of the floodplain and there is no need to prevent flooding except property protection.

\section{Acknowledgements}

The presented research was founded by the Research project VaV SM2/57/05 "Long-term changes in fluvial ecosystems in floodplains affected by extreme floods" of the Ministry of Environment of the Czech Republic and by the Research Plan MSM 0021620831 "Geographical Systems and Risk Processes in the Context of Global Changes and European Integration” of the Czech Ministry of Education which is fully appreciated.

\section{References}

BLAŽKOVÁ, D. (2003): Pobř̌žní vegetace řeky Berounky dva měsíce po povodni v srpnu 2002. Bohemia centralis 26, 35-44.

GEERLING, G.W. et al. (2006): Succession and rejuvenation in floodplains along the river Allier (France). Hydrobiologia 565, 71-86.

HAMZAAND, M.A., ANDERSON, W.K. (2005): Soil compaction in cropping systems. A review of the nature, causes and possible solutions. Soil \& Tillage Research 82 (2), 121-145.

HÖLZEL, N., OTTE, A. (2001): The impact of flooding regime on the soil seed bank of flood-meadows. Journal of Vegetation Sicence 12, 209-218.

KOUTECKÝ, P. (2003): Změny vegetace aluviálních luk po povodních (jižní Morava). Zprávy ČBS 38, 111-115.

KOVÁŘ, P. et al. (2002): Vegetační sukcese v nivě řeky pět let po záplavě. Živa 88 (6), 253-257.

LACINA, J. et al. (1998): Sledování sukcese vegetace a vývoje říčního koryta ve vybraných profilech Bečvy mezi Osekem n. B. a Valašským Meziříčím. Výzkumná zpráva, Ústav geoniky AV ČR, Brno. 
MATĚJČEK, T. (2007): Sledování výskytu invazních druhů rostlin v říčních nivách. In: Langhammer, J. (ed.): Změny v krajině a povodňové riziko. Sborník př́ispěvkủ semináře Povodně a změny v krajině, PřF UK, Praha, 121-126.

NAIMAN, R.J., DÉCAMPS, H. (1997): The ecology of interfaces: Riparian Zones. Annual Review of Ecology and Systematics, 28, 621-658.

SLAVÍK, B. (Ed.) (1997): Květena České republiky. 5. Academia, Praha.

TOWNSEND, P.A. (2001): Relationship between vegetation patterns and hydroperiod on the Roanroke River floodplain, North Carolina. Plant Ecology, 16, 43-58.

\section{Résumé \\ Sukcese vegetace a přeměna pokryvnosti půdy po extrémních záplavách Př́ípadová studie v nivě Sázavy}

Vliv extrémních záplav na vegetaci a půdní kryt byl studován v nivě Sázavy po jarní povodni v roce 2006. V prostoru nivy mezi Čerčany a Pořičím nad Sázavou došlo k rozsáhlé erozi a sedimentaci. Sledována byla jednak obnova aluviální vegetace pohřbené pod málo mocné vrstvy sedimentu, jednak sukcese vegetace na erozních plochách a mocných sedimentech. Regenerace aluviální vegetace byla rychlá. Pokryvnost vegetace disturbovaných ploch dosáhla po 8 měsících stejné pokryvnosti jako na plochách nedisturbovaných. Oproti předpokladu nebyla prokázána rozdílná rychlost zarůstání studovaných ploch (regenerující vegetace aluviálních luk, sukcese na erozních plochách a sukcese na sedimentech). Druhové složení vegetace na sukcesních plochách však bylo průkazně závislé na typu plochy. Druhové složení také průkazně závisí na typu plochy a sukcesním stáří.

RNDr. Tomáš Chuman, Ph.D.

Charles University in Prague, Faculty of Science Department of Physical Geography and Geoecology

Albertov 6

12843 Prague 2

Czech Republic

e-mail: chumant@natur.cuni.cz 